\title{
Lahar at Kali Konto after the 2014 Eruption of Kelud Volcano, East Java: Impacts and Risk
}

\author{
Suprapto Dibyosaputro ${ }^{1}$, Gilang Arya Dipayana ${ }^{2}$, Henky Nugraha $^{3}$, Kartika Pratiwi $^{4}$, \\ Hogy Prima Valeda ${ }^{4}$ \\ ${ }^{1}$ Department of Environmental Geography, Faculty of Geography, UGM \\ ${ }^{2}$ Research Center for Disaster, UGM \\ ${ }^{3}$ Master Program on Management Planning of Watershed and Coastal Area, Faculty of Geography, UGM \\ ${ }^{4}$ Master Program on Geo-information for Spatial Planning and Disaster Risk Management, Graduate School, UGM \\ Corresponding E-mail: praptodibyo@gmail.com
}

\begin{abstract}
Five days after the Kelud Volcano eruption of 13 February 2014, lahar occurred in several channels of the Volcano. Rainfall with intensity of $26 \mathrm{~mm} /$ hour mobilized pyroclastic material from the upper slopes of Kelud Volcano down the channel during 3.5 hour. Using this eruption as a case study, the aims of this paper are (1) to study the geomorphic impact of lahars and (2) to study future hazards and risks due to the potential of lahar source material and lahar repose area. To reach these two goals, we use both primary and secondary data. The primary data comprises an integration of remote sensing, GIS approach, and fieldwork control, in order to investigate the geomorphic impacts of lahars. Secondary data were collected through interviews and statistical approach in villages, in order to determine their perception to the risk of lahar. Morphogenic processes such as riverbank erosion, channel-widening and riverbed downcutting took an important role in generating the impact of lahar in Kali Konto. The medial and distal areas were affected more largely affected than the proximal area. This major impacts have been river widening and buried crop field inside of the channel. This result allowed us to provide recommendation to population living along those areas at risk, in order to be prepared against the eventuality of potentially large and destructive lahars.
\end{abstract}

Key Words: Lahar, Kelud, Geomorphic impacts, Risk

\begin{abstract}
Abstrak
Lima hari setelah letusan gunung berapi Kelud 13 Februari 2014, lahar terjadi di beberapa sungai dari gunung berapi. Curah hujan dengan intensitas $26 \mathrm{~mm} / \mathrm{jam}$ membawa bahan piroklastik dari lereng atas Gunung Kelud ke lereng bawah selama 3,5 jam. Penelitian ini menggunakan letusan ini sebagai studi kasus dengan tujuan (1) untuk mempelajari dampak geomorfik dari lahar dan (2) untuk mempelajari potensi bahaya dan risiko karena potensi sumber lahar dan pada lahar daerah tidur. Untuk mencapai dua tujuan tersebut, kami menggunakan baik data primer dan sekunder. Data primer terdiri dari integrasi penginderaan jauh, pendekatan GIS, dan kontrol lapangan, untuk menyelidiki dampak geomorfik dari lahar. Data sekunder dikumpulkan melalui wawancara dan pendekatan statistik di beberapa desa, untuk menentukan persepsi mereka terhadap risiko lahar. Proses morphogenic seperti erosi tepi sungai, pelebaran alur sungai dan penghancuran tubuh sungai mengambil peran penting dalam menghasilkan dampak lahar di Kali Konto. Daerah medial dan distal yang mempengaruhi lebih sebagian besar dipengaruhi dari daerah proksimal. Dampak besar ini telah terjadi adalah pelebaran sungai dan terkuburnya persawah an. Hasil ini memungkinkan kami untuk memberikan rekomendasi kepada penduduk yang tinggal di sepanjang daerah-daerah yang berisiko, untuk siap menghadapi kemungkinan dari lahar yang berpotensi besar dan merusak.
\end{abstract}

Kata kunci: Lahar, Kelud, dampak geomorfik, Risiko

\section{Introduction}

Kelud Volcano (1731 m. asl) is one of the hazardous volcanoes in Indonesia (Kusumadinata, 1972; Pratomo, 1992; Bourdier et al., 1997), which is located in East Java aligned with Kawi-Butak, Anjasmoro Mountain, and Arjuno-Welirang Volcano (Fig. 1). Kelud Volcano is of explosive eruption type. Often accompanied by pyroclastic density currents (PDC's), tephra fall, and syn- or post-eruptive lahar (Zen and
Hadikusumo, 1965; Sudradjat, 1991; Bourdieret al., 1997a, b; Thouret et al., 1998; Cronin et al., 2000; Lavigne and Thouret, 2000, 2002). After 1300 AC, Kelud Volcano erupted about 30 times (Hageman (1867), Houwink (1901), Kemmerling (1921), Van Padang (1951), Hadikusumo (1967), Kusumadinata (1979), and Pratomo (1992) generating more than 15.000 fatalities during or after the eruptions (De Belizal et al., 2012). 


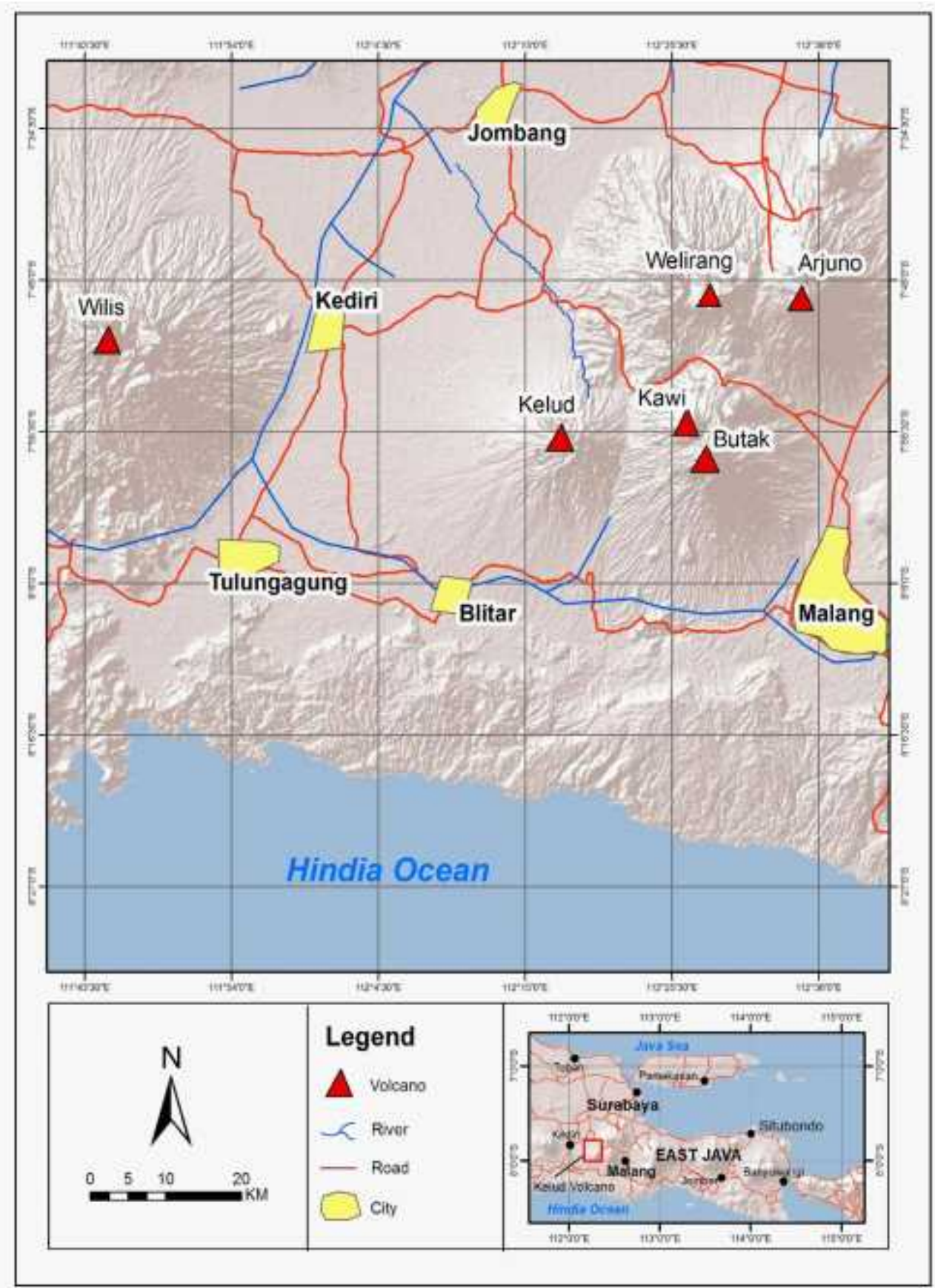

Figure 1. Location and morphological overview of Kelud Volcano Region

Lahar at Kelud Volcano is one of the most hazardous phenomena during and after the period in addition to primary hazards (Bourdier et al, 1997a, b; Thouret et al., 1998; Cronin et al., 2000; Lavigne and Thouret, $2000,2002)$. Lahar flow is a threat to $\sim 160,000$ people in Kediri, Tulungagung, Blitar and (Thouret et al, 1998; Jeffrey et al., 1998), especially for those who live along the river channel. Lahar as secondary hazards have high destructive power than the material results of the primary activities of volcanoes such as various kinds of airborne material (bombs, lapilli, sand, dust and ash) (Blong, 1984), because of high discharge lahar flows $\left(<10-107 \mathrm{~m}^{3} \mathrm{~s}\right.$ $\left.{ }^{1}\right)$, and can achieve a considerable area $(>100 \mathrm{~km})$ and has a long period of destruction of land in an area that was devastated by lahar (Pierson, 1998; Yokohama, 1999; Mayor et al, 2000). Ten rivers that disgorge at Kelud Volcano, lahar had been flowing since 1000 AC (see Table 1) (Thouret et al., 1998). Some examples of lahar incident in 1991 caused 9,000 houses damaged and the deaths of $\sim 15,000$ inhabitants, while the lahar in 1919 led to the deaths of 1586 people (Kemmerlin, 1921; Thouret et al., 1998). 
Table 1. History of lahar events in river at the foot of Kelud Volcano

\begin{tabular}{|c|c|c|c|c|c|c|}
\hline \multirow[t]{2}{*}{ Date } & \multicolumn{2}{|c|}{ Type of Lahar } & \multirow[t]{2}{*}{ River } & \multirow{2}{*}{$\begin{array}{c}\text { Maximum } \\
\text { Extent } \\
(\mathbf{k m})\end{array}$} & \multirow[t]{2}{*}{ Trigger Processes } & \multirow[t]{2}{*}{ Casualties } \\
\hline & $\begin{array}{l}\text { Syn- } \\
\text { Eruptive }\end{array}$ & $\begin{array}{l}\text { Post- } \\
\text { eruptive }\end{array}$ & & & & \\
\hline 1334 & $*$ & $?$ & ? & $?$ & Lake Outburst & $?$ \\
\hline 1586 & $*$ & $?$ & ? & ? & Lake Outburst & $>10000$ \\
\hline $\begin{array}{l}11-14 \\
\text { October } \\
1826\end{array}$ & $*$ & $?$ & $\begin{array}{l}\text { Semut, Gedog, } \\
\text { Lekso, } \\
\text { Siwalan, } \\
\text { Bedali, Putih }\end{array}$ & $?$ & Lake Outburst & Any \\
\hline $\begin{array}{l}\text { 16-17 } \\
\text { May } 1848\end{array}$ & $*$ & $*$ & $\begin{array}{l}\text { Konto, Putih, } \\
\text { Lekso, } \\
\text { Siwalan, } \\
\text { Brantas }\end{array}$ & $24-27$ & $\begin{array}{l}\text { Crater wall coll apse, } \\
\text { Lake Outburst }\end{array}$ & 22 \\
\hline $\begin{array}{l}31 \\
\text { January } \\
1864\end{array}$ & $*$ & $*$ & & $24-27$ & $\begin{array}{l}\text { Lake Outpuring, } \\
\text { Pyroclastic flow }\end{array}$ & Any \\
\hline $\begin{array}{l}29 \\
\text { January } \\
1875\end{array}$ & $\begin{array}{l}\text { No } \\
\text { eruption }\end{array}$ & * & Bladak & $?$ & $\begin{array}{l}\text { Crater wall collapse, } \\
\text { Lake Outpuring }\end{array}$ & Any \\
\hline $\begin{array}{l}22-23 \\
\text { May } 1901\end{array}$ & $*$ & $*$ & Ngobo-Pulo & 27 & $\begin{array}{l}\text { Lake outburst, } \\
\text { Pyroclastic flow, } \\
\text { pyroclastic surge and } \\
\text { fall, }\end{array}$ & Any \\
\hline $\begin{array}{l}20 \text { May } \\
1919\end{array}$ & * & $*$ & All rivers & $27-37,5$ & $\begin{array}{l}\text { Lake outburst, } \\
\text { Pyroclastic flow, } \\
\text { pyroclastic surge and } \\
\text { fall }\end{array}$ & 5110 \\
\hline $\begin{array}{l}31 \text { August } \\
1951\end{array}$ & $*$ & $*$ & All rivers & $6,5-12$ & $\begin{array}{l}\text { Lake outburst, } \\
\text { Pyroclastic flow, } \\
\text { pyroclastic surge and } \\
\text { fall }\end{array}$ & Any \\
\hline 24-Apr-66 & $*$ & $*$ & $\begin{array}{l}\text { Bladak, Senut, } \\
\text { Putih, Ngobo- } \\
\text { Pulo, Konto, } \\
\text { Mangli, } \\
\text { Sumberagung, } \\
\text { Konto, } \\
\text { Petungkobong, } \\
\text { Gedog }\end{array}$ & $\begin{array}{l}7 ; 18,5-21 \\
24-29,5\end{array}$ & $\begin{array}{l}\text { Lake outburst, } \\
\text { Pyroclastic flow, } \\
\text { pyroclastic surge and } \\
\text { fall }\end{array}$ & 211 \\
\hline $\begin{array}{l}\text { February- } \\
\text { March } \\
1990\end{array}$ & & * & $\begin{array}{l}\text { Konto, } \\
\text { Mangli, Abab, } \\
\text { Bladak, } \\
\text { Gedog, } \\
\text { Petukobong, } \\
\text { Sumberagung, } \\
\text { etc }\end{array}$ & $7-37,5$ & $\begin{array}{l}\text { Lake outburst, } \\
\text { Pyroclastic flow, } \\
\text { pyroclastic surge and } \\
\text { fall }\end{array}$ & \\
\hline 2007 & & $*$ & $?$ & ? & $?$ & ? \\
\hline 2014 & & $*$ & Konto; Bladak & ? & $?$ & ? \\
\hline
\end{tabular}


On 13 February 2014 one and a half hour after the government rose the danger level of volcanic activity, at 22:50 (local time), a Plinian eruption took place. Ash fell in the region in all directions from the vent. This eruption created an eruption column that reached $\sim 25 \mathrm{~km}$ and that was distributed almost on half of Java Island. After the 2014 eruption, about $50 \times 10^{6} \mathrm{~m}^{3}$ of material was deposited on the upper slope of Kelud Volcano. This material has then been remobilized by rainfalls and generated lahar along the river under Kelud Volcano._In 18 February 2014, first lahar after Kelud eruption 2014 was occurred in several rivers (Kali Ngobo, Mangli (Kediri), Kali Bladak (Blitar), and Kali Konto (Kediri-Malang). Kali Konto (Fig. 2) is one of river that located in northern part of Kelud Volcano that repeatedly experience of lahar events. Historically in recent 100 years, Kali Konto was affected due to lahar in 1919, 1951, 1966, 1990, and 2007. Lahar events at Kali Konto was evidenced by the construction of physical mitigation infrastructure such as dyke in Blaru village and SABO DAM along the river channel.

Risks of related to lahars at Kelud Volcano, must consequently be updated in the aftermath of the 2014 eruption. Indeed, the issues of lahar hazards that have become more frequent and more widespread due to large material present in the upper part of the Kali Konto needs to be addressed; and this paper focus on two related issues, (1) lahars that led to several impacts on river channels on the slope of the volcano, creating lahar corridors which damaged houses, agricultural land, and irrigation located along the Kali Konto. (2) People around Kali Konto more vulnerable due to repetition of lahar in wet season and risk assessment needs to be done due to future lahar potential.

\section{Methods}

To reach the objectives, we used a methodology combining primary data gathered from the field and remote sensing; and secondary data obtained from local authorities:

(1) Geomorphology impact was identified using integration of remote sensing, GIS approach, and fieldwork checking. Lahar corridors was identified by compare two satellite imagery from Quckbird 2009 (1 meter resolution) and Formosat 2014_(2 m resolution). Both of images were analyzed using object based image analysis (OBIA) method to identify lahar corridor along river path and compare to delin- eate segmented lahar corridor in upstream, midstream, and downstream along the Kali Konto.

(2) Field investigation of the Kali Konto during March-August 2014. Field analysis involved: (a) ground-truthing areas of the Kali Putih to verify remotely-sensed findings, (b) mapping lahar deposit thickness with point measurements in proximal, medial, and distal site (see Fig. 2), and (d) categorizing, mapping, and classifying the level of damage house, agricultural land, and infrastructure resulting from lahar activity.

(3) Interviews with local people will be done in order to determine their perception to the risk of lahar. Semistructured questionnaire will be conducted for these training areas. Interviews were conducted with village chief and the key person in each village in the study area. This step also used combination of interview using questioner and secondary data from PODES (Potensi Desa) and KDA (Kecamatam Dalam Angka).

\section{Results and Discussion}

\section{February $18^{\text {th }}$, 2014 lahar at Kali Konto}

Kali Konto is a main river that extends for $47 \mathrm{~km}$, starting near the summit of Kelud Voclano. The headwater are located on Kelud Volcano, near Mount Lokak, and Mount Leksongo (that located in eastern part of Kali Konto). Lahar in Kali Konto have occured 5 days after peak phase of the Kelud Volcano eruption (13 February 2014). This lahar triggered by 26 $\mathrm{mm} /$ hour rainfall during 3,5 hour. There was remobilized pyroclastic material from upperpart of Kelud Volcano. There are any three factors that can explain why first lahar preferentially occurs in Kali Konto which are related to the rainfall, the deposit distribution and the drainage system.

February 2014 during lahar event period (04.00 - 07.30 PM at local time) at northern and western slope of Kelud Volcano. (2) Large fallout tephra, which was deposited on the west, east, and north slopes of Kelud, due to thedominant wind direction during the eruption. Tephra fall with large grain-size (Õ 2-17 cm) was deposited in northern and eastern slope. This tephra fall was damaged several villages (such as Pagersari, Pandansari, and Banturejo Villages), in in eastern slope of Kelud Volcano. (3) Existence of drainage system in Konto watershed with deserve morphometric and the presence of erodible material along river channel. 


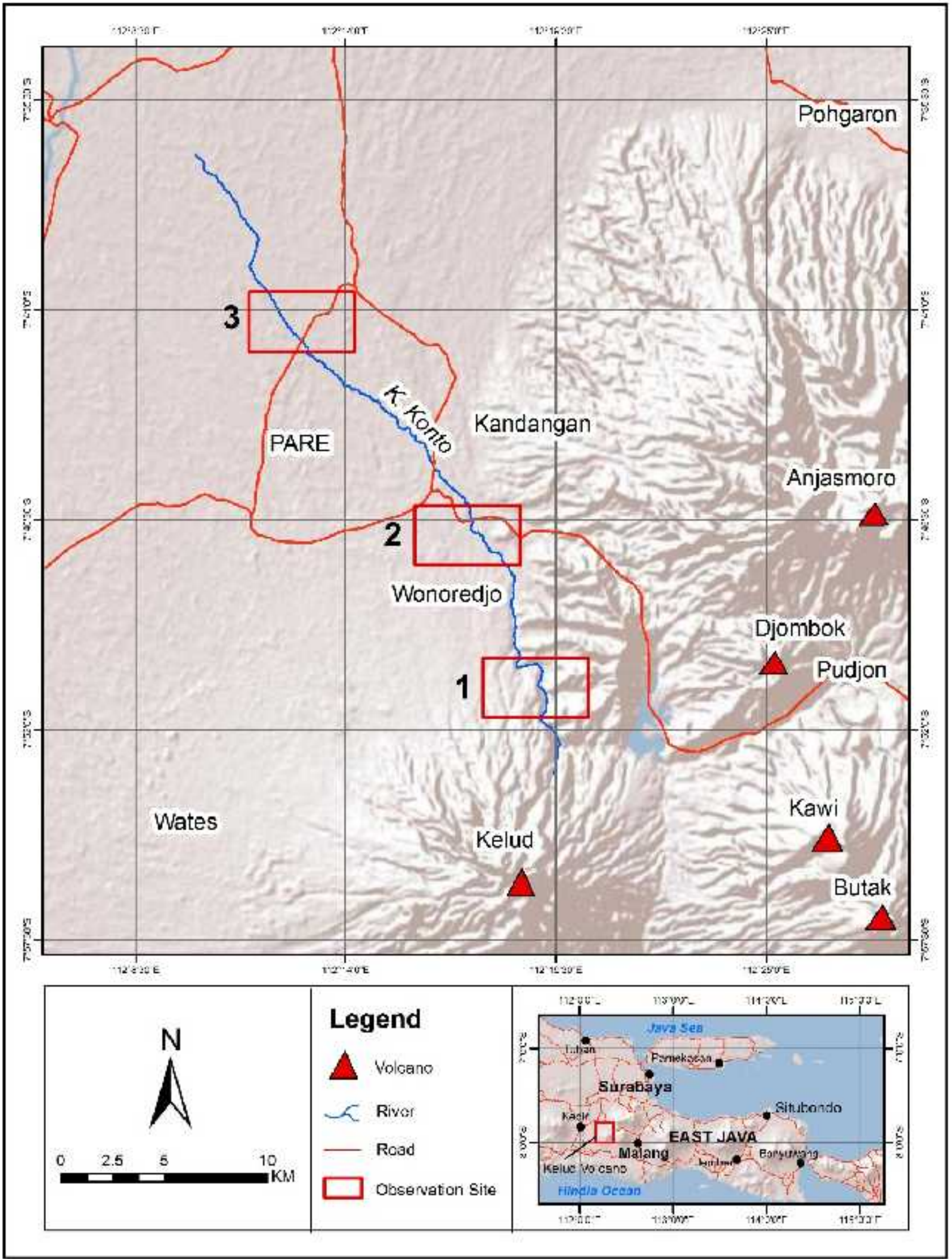

Figure 2. Volcano and observation site in proximal (1), medial (2), and distal (3) areas (red boxs). Location Kali Konto at northern slope of Kelud Volcano. 
In 1919, lahar in Kali Konto travelled long distances down valley up to $27- \pm 37 \mathrm{~km}$ (Thouret et al., 1998). In 1990, several SABO DAM and sediment traps have been constructed in the valley channels of Kali Konto and they reduced the travel distance of lahar to 10 $\mathrm{km}$ for debris flows and $27 \mathrm{~km}$ for hyperconcentrated and stream flow. And nowadays, lahar after 2014 eruption has caused disruption in transportation due to closure of the bridge in Kandangan ( $25 \mathrm{~km}$ from summit) (Damarwulan Bridge; connecting Kediri and Malang) and Badas (37 km from summit) (Badas Bridge; connecting Kediri and Jombang). Lahar in Kali Konto also damaged Siman reservoir (13 km from summit) and has threatened the irrigation system in Siman, Besowo, and Brumbung Village. In eastern part of Kelud Volcano, lahar covered Selorejo Reservoir with $\sim 2,8$ million $\mathrm{m}^{3}$ material from lahar in Kali Sambong (first river network of Kali Konto). Lahar run out distance in Kali Konto exceed $40 \mathrm{~km}$ for hyperconcentrated lahar and stream flow and $23 \mathrm{~km}$ of debris flow.

Recording of lahar motion show the characteristic of lahar such as peak discharge and velocity. Lahar was recorded in two locations, in Damarwulan Bridge and in Blaru Village. Due to the limitations of recording equipment and methods, we only gets recording several time of lahar events by courtesy of the local people. However, we could study about lahar velocity in two observatory locations, Lahar at Damarwulan Bridge started at 04.17 PM (at local time). At Blaru village (in the distal part (box No. 3 in Fig. 2) lahar recorded with velocity $\sim 2-7 \mathrm{~m} / \mathrm{s}$. Lahar discharge recorded reaches $420 \mathrm{~m}^{3} / \mathrm{s}$ in Blaru village. This lahar close similar with lahar in 28 February 2011 and 14 March 2011 in Kali Gendol, Merapi Volcano (peak discharge $540 \mathrm{~m}^{3} / \mathrm{s}$ and 410 $\mathrm{m}^{3} / \mathrm{s}$ ) (De Belizal et al., 2013). This difference is lahar at Kali Konto has smaller grain size material than lahar at Kali Gendol.

\section{Geomorphic impacts of lahar in Kali Konto re- lated damages}

Lahar in Kali Konto was occurs no more than a week after eruption phase. Nearly $25 \mathrm{~km}^{2}$ area was af-

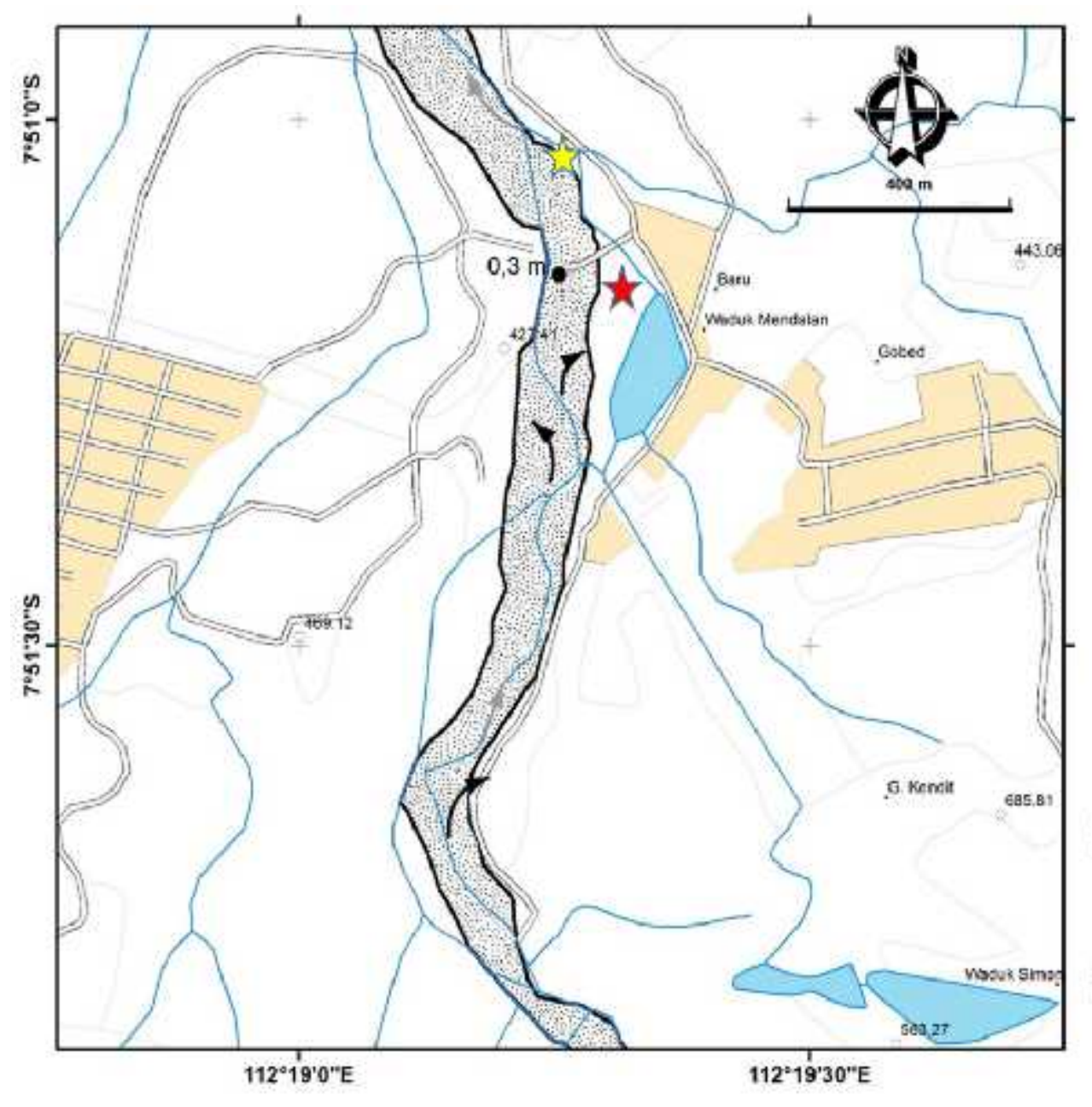

\section{PLTA Mendalan}

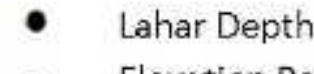

- Elevation Point

River channel

- Riverbank

- Road
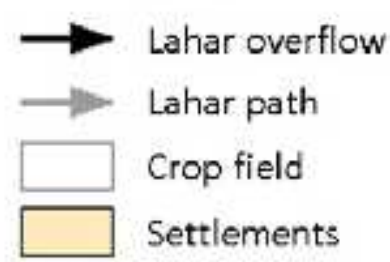

Lahar corridors

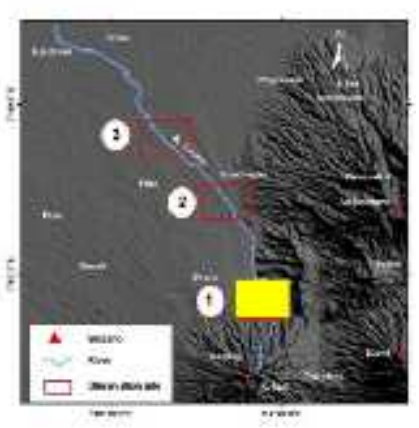

Figure 3. Formation of lahar corridors on the proximal slope at Mendalan site 
fected due to lahar in Kali Kanto. River channel also were affected by lahar and by their morphogenic processes such as: riverbank erosion, channel widening and riverbed downcutting. These processes take an important role in generating the impact of lahar in Kali Konto. Impact of lahar that generated by lahar and geomorphic processes were observed in three locations (Fig.2) that represent three zones (proximal, medial, and distal area), This locations are Mendalan (represent proximal noticed number 1, Damarwulan and Kandangan in medial area, noticed as number 2, and Blaru, Badas_noticed number 3 .

Proximal part in Mendalan (Number 1 in Fig. 2) of the Kali Konto experienced some changes as a result of lahar on 18 February 2014. Lahar was caused river widening which threatens settlement and crop field on the riverbank (Fig. 3). Before the 2014 eruption, the proximal part of the Kali Konto atMendalan was a small channel between $1.5 \mathrm{~m}$ and $2 \mathrm{~m}$ deep and 5-10 m wide. After first lahar in Kali Konto created 75-100 m wide corridors and the channel fully by lahar material. It expanded with crop field in eastward and westward of river channel. 42 houses, road network, and hydroelectricity building near the river (50-150 m) (a part of PLTA (Pembangkit Listrik Tenaga Akhir) Mendalan (Red Mark in Fig. 3)_po- tentially damaged on the future lahar due to the pattern of river widening and lahar over flow or avulsion. The depth of the lahar reached $0.3 \mathrm{~m}$ to $1.2 \mathrm{~m}$ and damaged 2.3 ha crop field (Fig. 4). Crop field was buried by lahar with fine sand up to pebbles material.

Contrary to the proximal slope, the medial slope of Kali Konto in Damarwulan, Kandangan more widespread than proximal slope. Impact of lahar in Damarwulan indicated by 6 houses and 1 mosque (Red Mark in Fig.5) that located in the river bank was buried by lahar (Fig.6). This houses are illegal house due to land owned by irrigation division of Public Work Department (Dinas Pekerjaan Umum (DPU)). This lahar potentially damage the settlement that located $30 \mathrm{~m}$ near the maximum lahar corridors. Lahar created $\sim 60$ meter wide corridors in eastward of river (before SABO DAM) and $\sim 40$ meter eastward and westward (after SABO DAM) (Fig.5). A part ofthe Damarwulan village was built on a 2-3 m high volcaniclastic terraceoverlooking the riverbed, and buried by 2014 lahar. The $0.5-1.5$ meter lahar deposited in riverbank which very fine to pebble dominated (Fig. 7). The large impact in this site was caused by the morphological condition that located in the knick point.
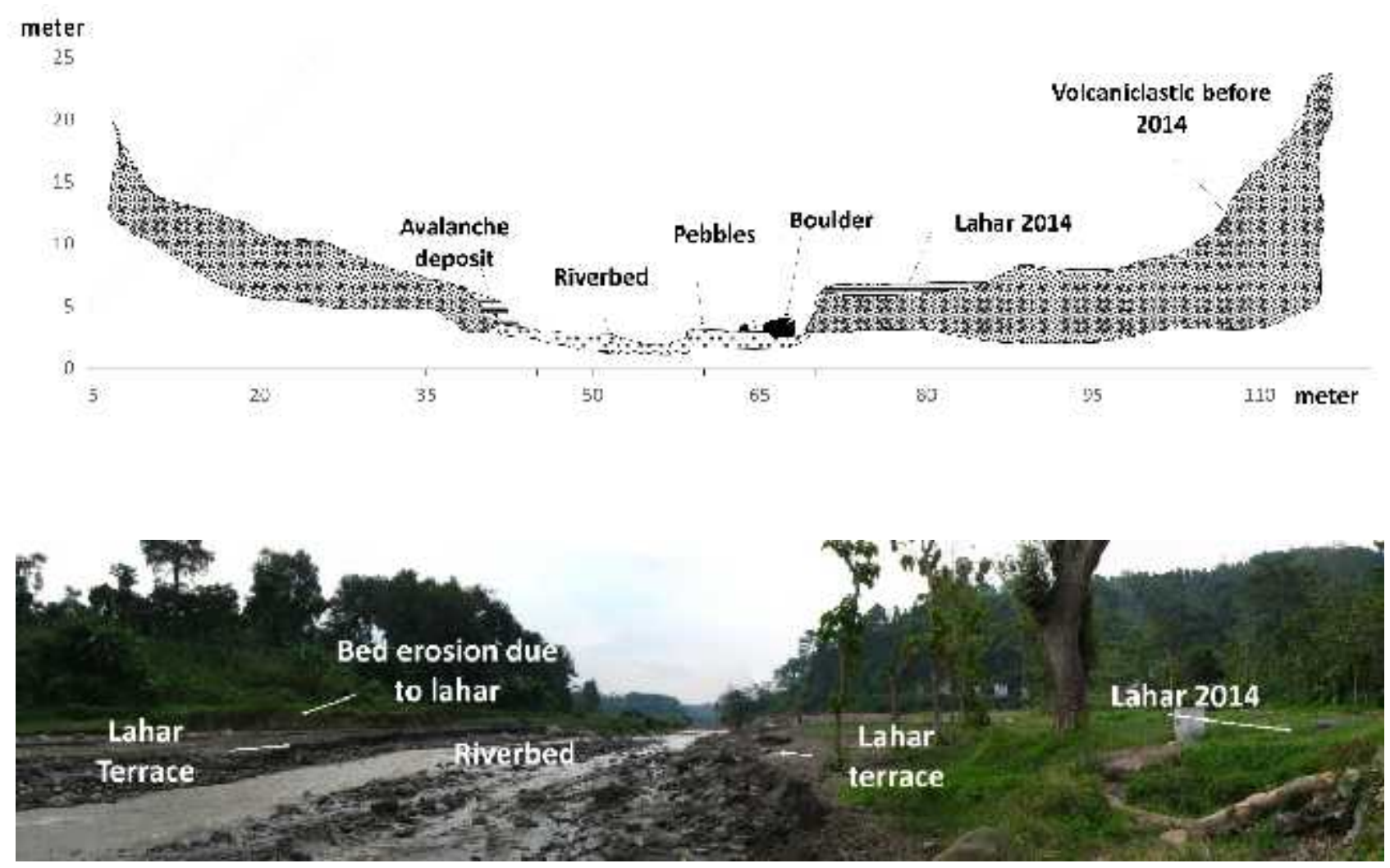

Figure 4. Cross-sectional the proximal slope at Mendalan site_(Yellow mark in Fig. 3) 
Contrary to the proximal slope, the medial slope of Kali Konto in Damarwulan, Kandangan more widespread than proximal slope. Impact of lahar in Damarwulan indicated by 6 houses and 1 mosque that located in the river bank was buried by lahar (Fig.6). This houses are illegal house due to land owned by irrigation division of Public Work Department. This lahar potentially damage the settlement that located $30 \mathrm{~m}$ near the maximum lahar corridors. Lahar created $\sim 60$ meter wide corridors in eastward of river (before SABO DAM) and $\sim 40$ meter eastward and westward (after SABO DAM) (Fig.5). A part of the Damarwulan village was built on a 2-3 m high volcaniclastic terraceoverlooking the riverbed, and buried by 2014 lahar. The $0.5-1.5$ meter lahar deposited in riverbank which very fine to pebble dominated (Fig. 7). The large impact in this site was caused by the morphological condition that located in the knick point.

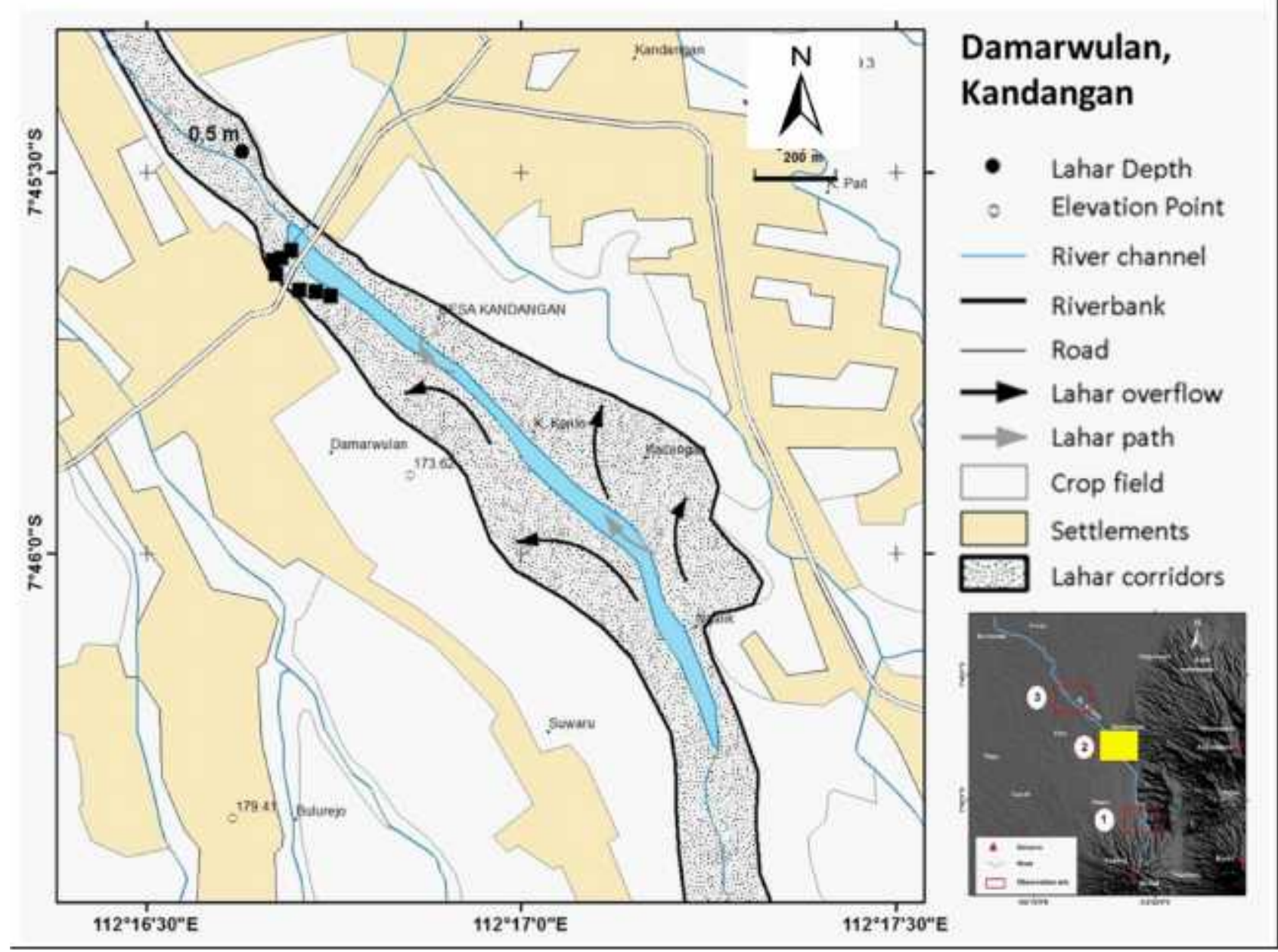

Figure 5. Formation of lahar corridors on medial slope at Damarwulan site 
Impact lahar in distal area showed in Blaru village that located $35 \mathrm{~km}$ from summit. Morphologically, this area located in gentle-flat slope. Historically, lahar more frequently has impacted in this location. It was evidenced of human made levee as far as $300 \mathrm{~m}$ from river side. Lahar caused river widening from 5 meter to $~ 25$ meter. Lahar corridors was exceed 300 meter in both of river side and buried crop field inside levee
(Fig. 8). Crop land was buried with lahar thickness 0.5-1 meter_(Fig. 9). Lahar deposit in Blaru different with lahar material in proximal and medial slope. Lahar overflow in the distal slope was bounded by artificial levee. The artificial levee built after lahar event 1919 to protect settlement and crop field in the vicinity. Lahar resulted aggradation in riverbed with fine-very fine sand material and it taken by mining activity (Fig. 10).

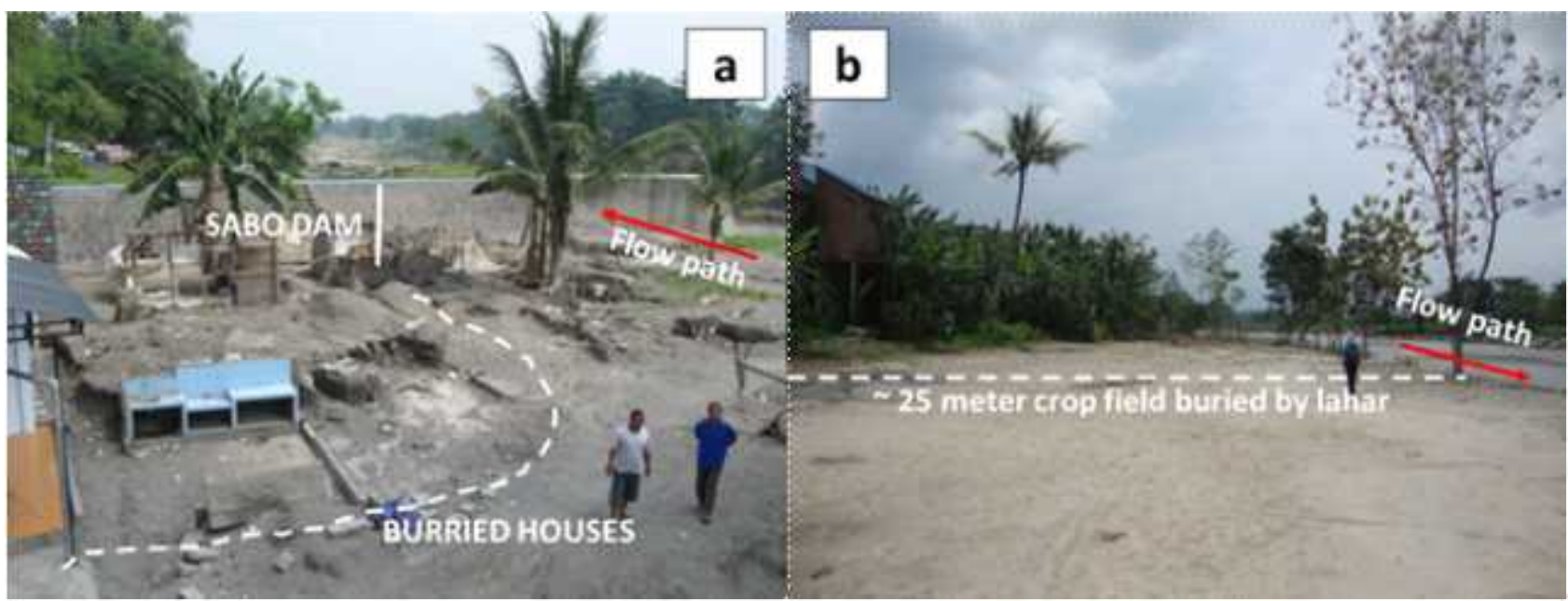

Figure 6. (a) The houses and mosque that damage due to lahar and (Red Mark in Fig.5) (b) crop field located in eastward of river channel covered by lahar (Yellow mark in Fig. 5)

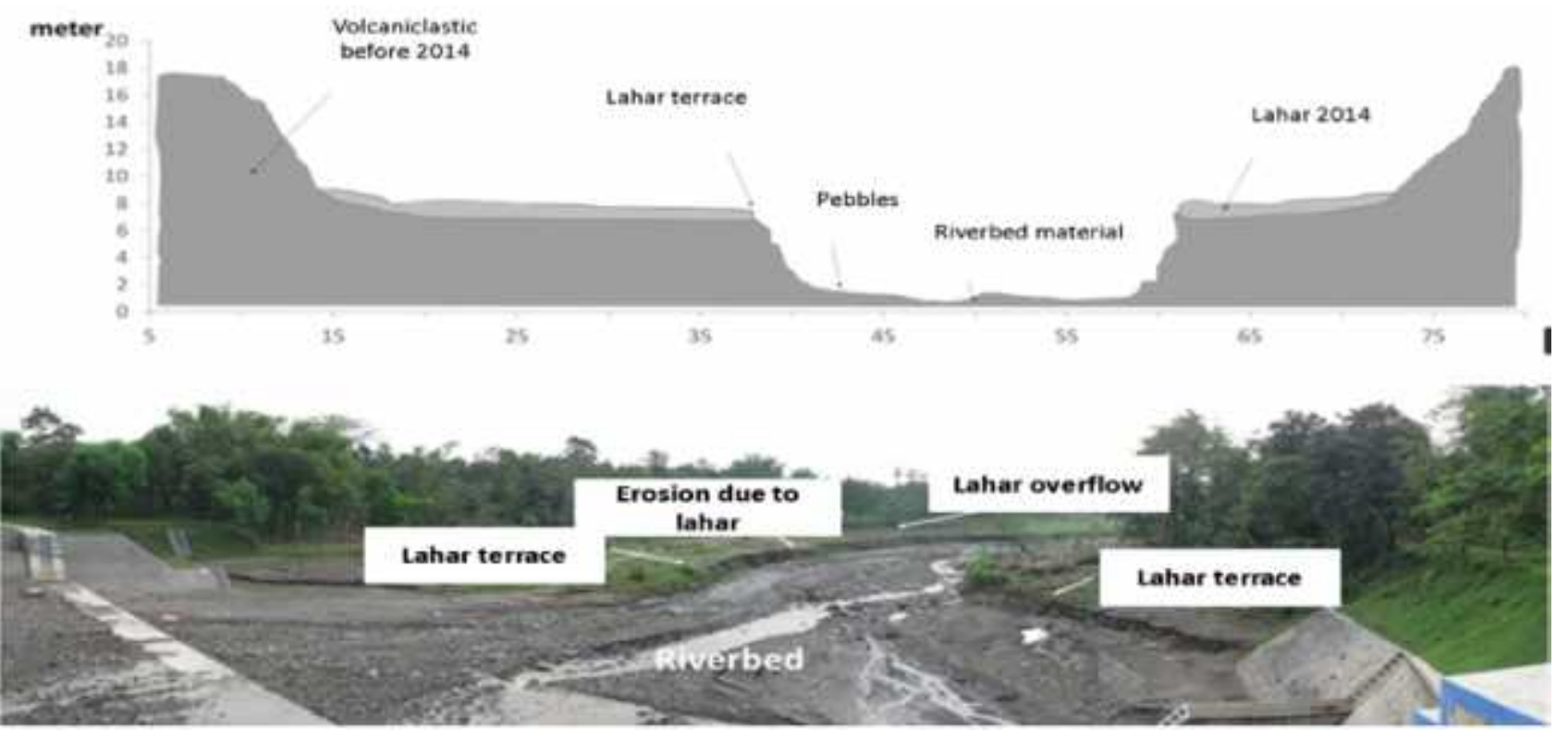

Figure 7. Cross-sectional on the medial slope at Kandangan site_(Red mark in Fig. 5) 


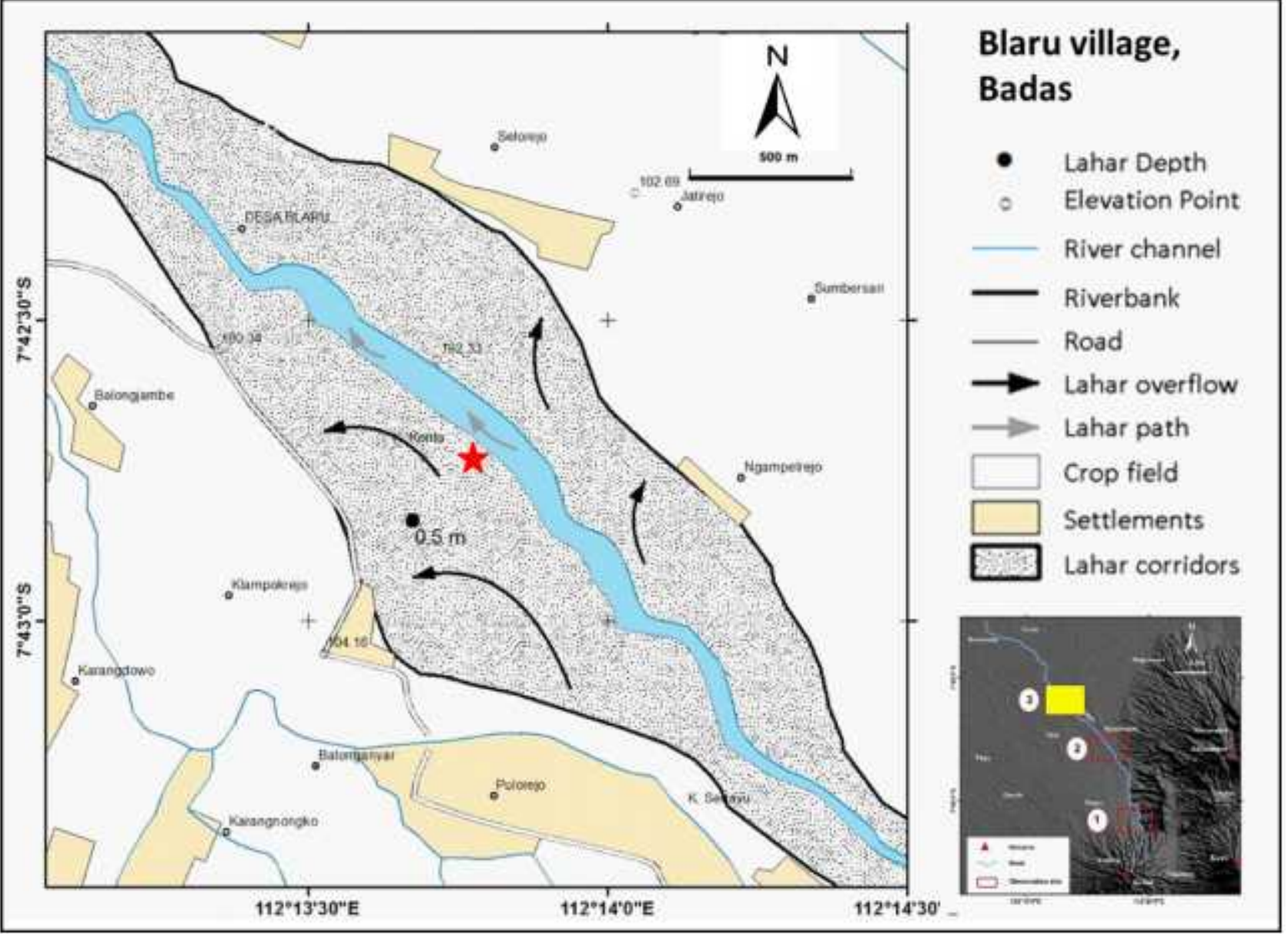

Figure 8. Formation of lahar corridors on the distal slope at Blaru site

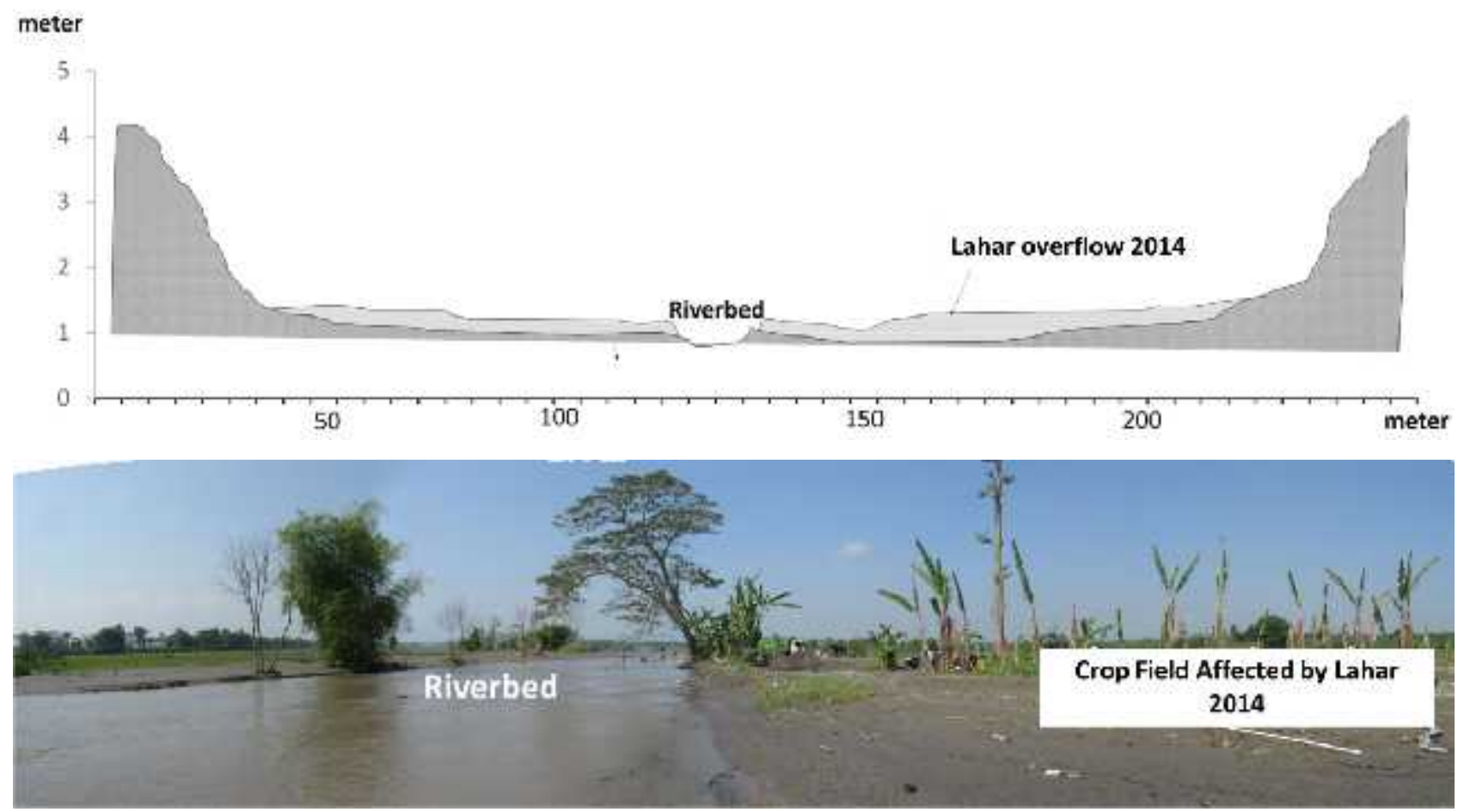

Figure 9. Cross-sectional on the distal slope at Blaru site (Red mark in Fig. 8) 


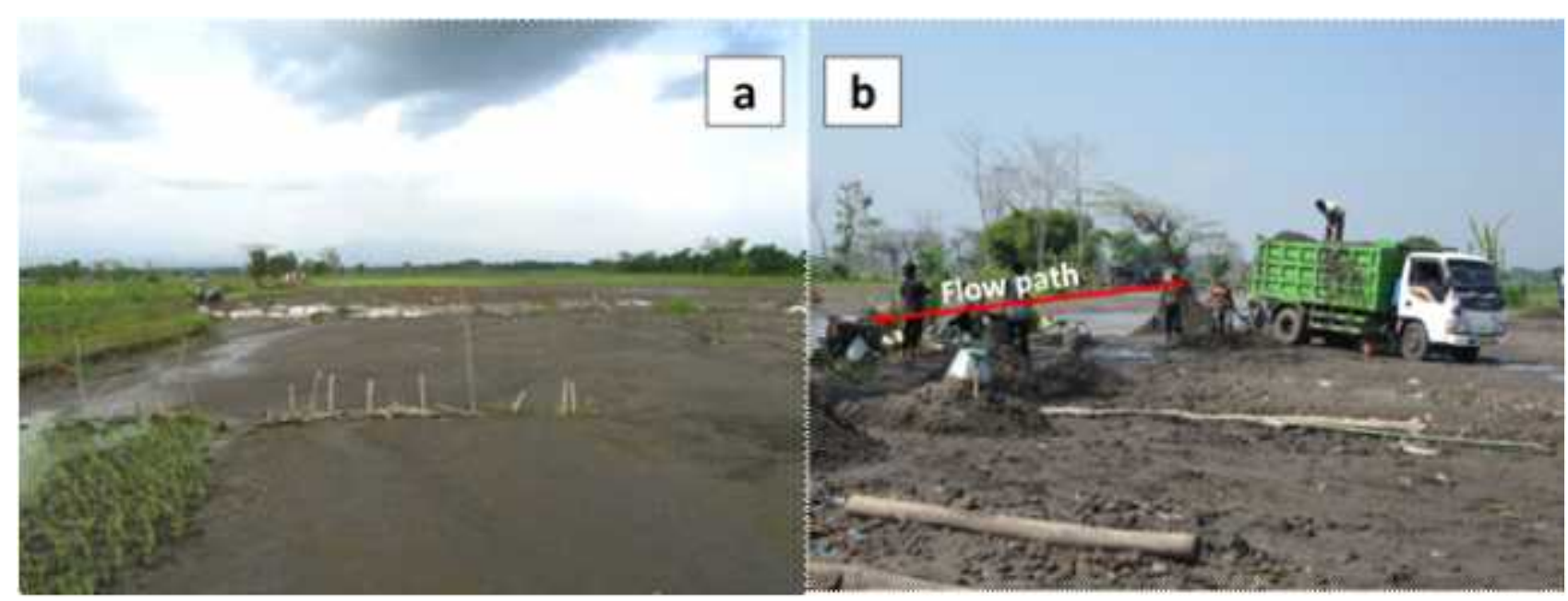

Figure 10. (a) Crop field inside the levee that buried by lahar and (b) mining activity in Kali Konto after lahar (Red mark in Fig. 8)

\section{Manage a risk for future lahar in Kali Konto}

Damage by the 2014 lahar was particularly important to houses, land and infrastructures at Kali Konto. After the 2014 eruption until September 2014 lahar in Kali Konto damaged 7 building in medial and distal slope, destroyed 4 bridges and SABO DAM, and cover 3 reservoir. Lahar also buried a hundreds hectare crop land along Kali Konto (including 34 Ha crop land in Kuwik village on distal area). The damagesrelated to the main geomorphic process related to lahar in Kali Konto (riverbank widening, riverbed downcutting, avulsions and overûows). The highway passing Damarwulan Bridgewas closed one time by lahar during 5 hour in 18 February 2014 . Whilst the road was being closed, generating trafûcjams on this road.

Associated with slightly frequent of lahar and large channel capacity, lahar did not reach settlements and did not cause a casualties. Although the eruption is ûnished, lahar hazards still threaten communities along the Kali Konto, where potentially damage particularly high related with this population was considered very "vulnerable" to natural hazards. Any several parameters that can be used to quantifying risk potential along Kali Konto based on village unit. There are population, area of crop field, and number of houses (Figure 11).

Number of population distribution showed the "urbanism" type of village along Kali Konto. Main road connecting Kediri and Malang take an important role of population distribution. Several villages under this corridors has large population (Kandangan, Klampisan, and Damarwulan with number of population > 8000) than other villages (Fig. 1a). This role similar with village under corridors road network Kediri-Jombang in Blaru and Badas villages (with number of population > 8000). Large number of population led to increased potential of loss. Settlement and crop field as the example sector that resulted from human activities. 

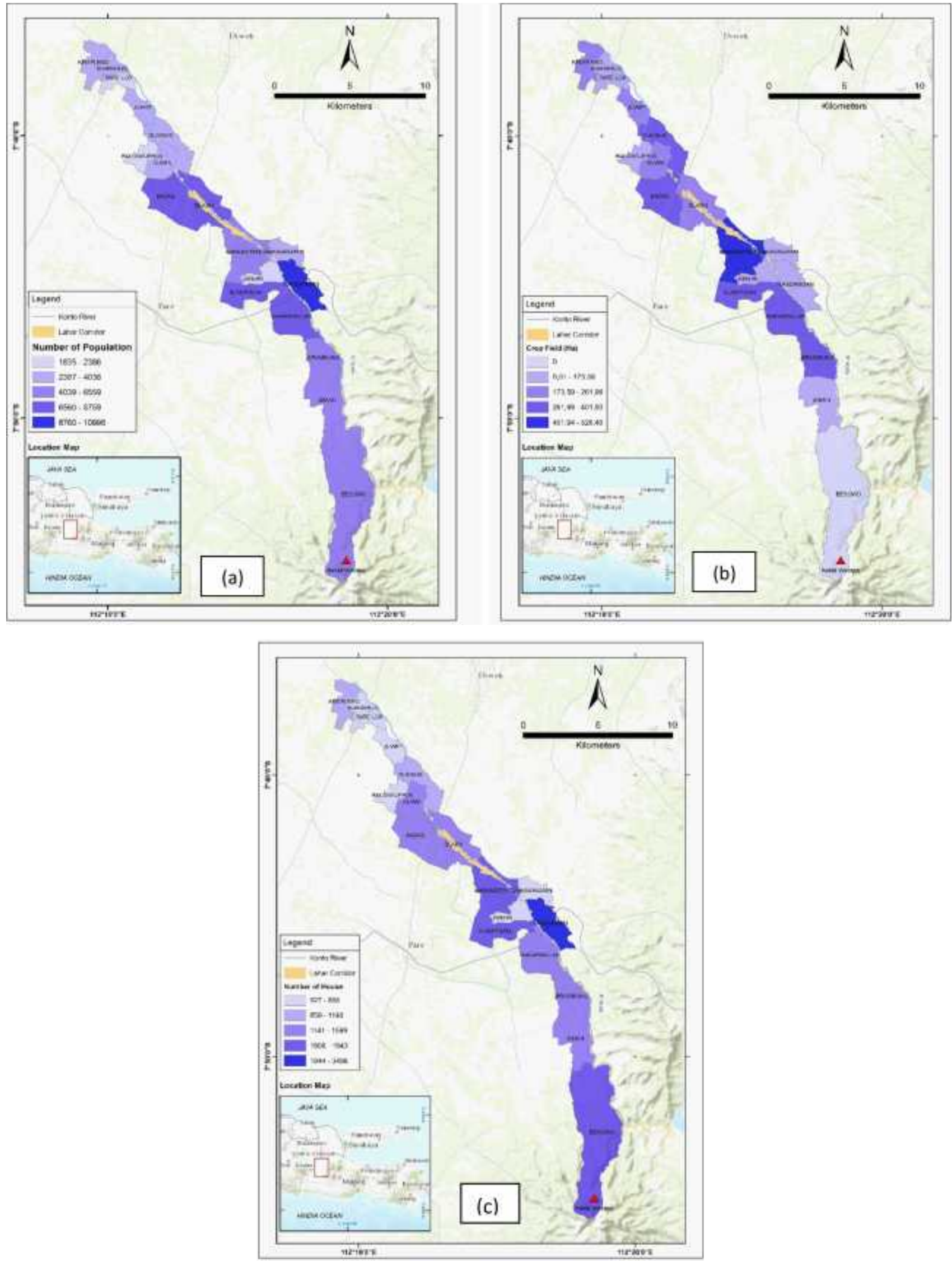

Figure 11. (a). Number of population, (b). Crop field inside the levee that buried by the lahar, and (c) number of houses buried by the lahar. 


\section{Conclusion}

Lahar impacts in the Kali Konto can't be considered major, especially because it happened only one time. However, the lahar left a distinct geomorphologic footprint.

At the distal site, lahar corridor is larger than in the medial area, due to the local "gentle-flat" slope condition. It is important to note that we did not observe any channel avulsion in the proximal area. In the medial area, riverbank erosion was more pronounced and further downstream in the distal area, the lahar spatial expansion was limited by the man-made levees.

Some notices should be considered for future lahar, because there is still a huge amount of volcaniclastic material in the proximal zone, and as the rainy season approaches, it might become a source of further lahars. People must be prepared for potential repetited lahars and a hazard map must be drawn to start proposing risk mitigation strategies.

\section{References}

Bourdier, J.L., Pratomo, I., Thouret, J.C., Boudon, G., Vincent, P.M., 1997a. Observations, stratigraphy and eruptive processes of the 1990 eruption of Kelut volcano, Indonesia. Journal of Volcanology and Geothermal Research 79, 181-203.

Bourdier, J.L., Thouret, J.C., Pratomo, I., Vincent, P.M., Boudon, G., 1997b. Menacesvolcaniques au Kelut (Java, Indonésie): les enseignements de l'éruption de 1990,324. C.R. Académie des Sciences, Paris, pp. 961-968.

Crandell DR, Booth B, Kusumadinata K, Shimozuru D, Walker GPL, Westercamp D 1984. Source-book for volcanic-hazards zonation. UNESCO, Paris

De Bélizal, E., Lavigne, F. Hadmoko, DS., Degeai, JP., Dipayana, G.A., Mutaqin, BW., Marfai., MA., Cooquet, M. Le Mauff, B., Robin, AK., Vidal, C., Choelik Noer and Aisyah, N. 2013. Rain-triggered lahars following the 2010 eruption of Merapi volcano, Indonesia: A major risk, Journal of Volcanology and Geothermal Research (2013), http://dx.doi.org/10.1016/j.jvolgeores.2013.01.010.

Fisher, R.V. \& Schmincke, H.-U.1984. Pyroclastic Rocks. Springer-Verlag, Berlin, 472 pp.

Gaillard, J.C., D'Ercole, R., Leone, F., 2001. Cartography of population vulnerability to volcanic hazards and lahars of Mount Pinatubo (Philippines): a case study in Pasig Protero River basin (province of Pampanga). Géomorphologie: relief, processus, environnement 3, 209-222.

Hadikusumo, D., 1967. Indonesian Bulletin of Volcanic Eruptions 6, 7-8.

Hageman, Jcz.J., 1867. Aanbieding van vulkanischeasch van de Keloeteruptie van 4 januari 1864, gevallente Soerabaia. Natuur Tijdschrift Nederlands Indië, 29.-410 pp.

Houwink, L., 1901. Verslag van den Onderzoek naar aanleiding van de uitbarsting vanden Vulkaan Keloet in den nacht van den 22 op den 23 mei 1901. Mijnwoordenboek Nederlands Oost-Indië, pp. 124-136. Jaarboek.

Iverson, R.M., Schilling, S.P. and Vallance, J.W., 1998, Objective Delineation of Areasat Risk from Inundation by Lahars. Geological Society of America Bulletin,Vol. 110, No. 8, p. 972-984.

Kemmerling, G.L.L., 1921. De uitbarsting van den G. Keloet in den nacht van den19den op den 20sten mei 1919. Weltevreden, Batavia. 121pp.

Kusumadinata, K., 1979. Data dasar Gunung api Indonesia. (Catalogue of references on Indonesian volcanoes with eruptions in historical times). Volcanological Survey of Indonesia report. $820 \mathrm{pp}$.

Janda, J.J., Daag, A.S., de los Reyes, P.J., Newhall, C.G., Pierson, T.C., Punongbayan,R.S., Rodolfo, K.S., Solidum, R.U. and Umbal, J.V., 1996. Assessment and Response to Lahar Hazard Around Mt. Pinatubo, 1991 to 1993. Dalam: Newhall, C. G and Punongbayan, R.S. (eds). Fire and Mud, Eruptions and Lahars of Mt. Pinatubo, Philippines. Quezon City/Seattle, PHIVOLCS/ University of Washington Press, p. 107140

Kerle, N., 2001, Remote Sensing Applied to the 1998 Lahar Disaster at Casita Volcano, Nicaragua. PhD Thesis, University of Cambridge, $204 \mathrm{p}$.

Lavigne F. and Suwa H., 2004. Contrasts between debris flows, hyperconcentrated flows and stream flows at a channel of Mount Semeru, East Java, Indonesia. Geomorphology, 61, 1-2: 31-58. 
Lavigne F. and Thouret J.-C., 2002. Sediment transportation and deposition by rain-triggered lahars at Merapi volcano, Central Java, Indonesia. Geomorphology, 49, 45-69.

Lavigne F. and Thouret J.-C., 2002. Sediment transportation and deposition by rain-triggered lahars at Merapi volcano, Central Java, Indonesia. Geomorphology, 49, 45-69.

Lavigne F., 1999. Lahars hazard micro-zonation and risk assessment in Yogyakarta city, Indonesia. GeoJournal, 49, $2: 131-138$.

Lavigne F., Thouret J.-C., Suwa H., Voight B., Young K., Lahusen R., Marso J., Sumaryono A., Dejean M., Sayudi D.S. and Moch, 2000. Instrumental Lahar Monitoring at Merapi Volcano, Central Java, Indonesia. Journal of Volcanology and Geothermal Research, 100: 457-478.

Lavigne F., Thouret J.-C., Suwa H., Voight B., Young K., Lahusen R., Marso J., Sumaryono A., Dejean M., Sayudi D.S. and Moch, 2000. Instrumental Lahar Monitoring at Merapi Volcano, Central Java, Indonesia. Journal of Volcanology and Geothermal Research, 100: 457-478.

Major, J.J., Pierson, T.C., Dinehart, R.L., Costa, J.,E., 2000. Sediment yield following severe volcanic disturbance - A two decade perspective from Mount St. Helens. Geology 28, 819-822.

Neumann Van Padang, M., 1951. Catalogue of the active volcanoes of the world. Part I. Indonesia Int. Volcan. Assoc, Napoli. 271 pp.

Pierson, T.C., 1998, An Empirical Method for Estimating Travel Times for Wet VolcanicMass Flows. Bulletin of Volcanology Vol. 60, Issue 2, p. 98-109.

Pierson, T.C., Daag, A.S., de los Reyes, P.J., Regalado, M.T.M., Solidum, R.U. and Tubianosa, B.S., 1996, Flow and Deposition of Hot lahars on the East Side of Mt. Pinatubo, July-October 1991. In Newhall, C.G and Punongbayan, R.S.(eds), Fire and Mud, Eruptions and Lahars of Mt. Pinatubo, Philippines. Quezon City/ Seattle, PHIVOLCS/ University of Washington Press, p. 921-950.

Pratomo, I., 1992. Étude de l'éruption de 1990 du volcan Kelut (Java-Est, Indonésie): sonapport à l'interprétation de l'activité historique du volcan. Unpublished PhD Thesis, Blaise Pascal Clermont-Ferrand II, 95 p

Rodolfo, K., 1989, Origin and Early Evolution of Lahar Channel at Mabinit, MayonVolcano, Philippines. Geological Society of America Bulletin, Vol. 101, No. 3,p. 414-426.

Rodolfo, K.S. and Arguden, A.T., 1991, Rain-Lahar Generation and Sediment Delivery Systems at Mayon Volcano, Philippines. In Fischer, R.V. and Smith, G.A. (eds), Sedimentation in Volcanic Settings. SEPM (Society for Sedimentary Geology) Special Publication No. 45, p. 71-87.

Smith G.A., and Fritz W.J., 1989: Penrose Conference report: Volcanic influences on terrestrial sedimentation. Geology 17: 376.

Sudradjat, A., 1991. A preliminary account of the 1990 eruption of Kelut volcano. Geologische Jaarboek 127, $447-462$.

Sudrajat, A., and Tilling, R. 1984. Volcanic hazards in Indonesia: The 1982-83 Eruptions of Galunggung: Episodes, v.7. no.2 June.1984, p.13-19

Thouret, J.C., Abdurachman, K.E., Bourdier, J.L. and Bronto, S., 1998, Origin, Characteristics, and Behaviour of Lahars following the 1990 Eruption of Kelud Volcano, Eastern Java. Indonesia. Bulletin of Volcanology, Vol. 59, Issue 7, p. 460-480.

Tuñgol, N. and Regalado, M.T., 1996, Rainfall, Acoustic Flow Monitor Records, and Observed Lahars of the Sacobia River in 1992. Dalam: Newhall, C.G and Punongbayan, R.S. (eds), Fire and Mud, Eruptions and Lahars of Mt. Pinatubo, Philippines, Quezon City/Seattle, PHIVOLCS/ University of Washington Press, p. 1023-1032.

Vallance, J.W. 2000. Lahars, Dalam Sigurdsson, H. Houghton, B.F Mc. Nutt,. S. Rymer, H.Stix, J. eds, Encyclopedia of vulcanoes: San Diego, Academic Press, p. 601-616

Wood N and Soulard C. 2009. Community exposure to lahar hazards from Mount Rainier, Washington: U.S. Geological Survey Scientific Investigations Report 2009-5211, 26 p.

Yokoyama, S., 1999, Rapid Formation of River Terraces in Non-Welded Ignimbrite along the Hishida River, Kyushu, Japan. Geomorphology, Vol. 30, Issue 3, p. 291-304. 